\title{
Direct measurement of aqueous mercury(II): Combining DNA-based sensing with diffusive gradients in thin films
}

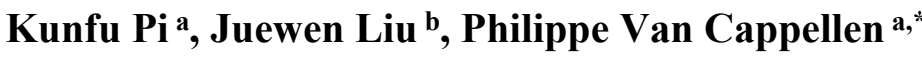

${ }^{a}$ Ecohydrology Research Group, Department of Earth and Environmental Sciences \& Water Institute, University of Waterloo, Waterloo, Ontario, N2L 3G1 Canada

${ }^{b}$ Department of Chemistry \& Waterloo Institute for Nanotechnology, University of Waterloo, Waterloo, Ontario, N2L 3G1 Canada

${ }^{*}$ Correspondence: Tel: +1-519-888-4567 ext. 31319; Fax: +1-519-746-7484; Email: pvc@uwaterloo.ca

\section{Supporting Information}

Supplementary information on experimental setup and additional results are provided.

Figure number: 3

Table number: 5 


\section{SI-I: Preparation of DNA-functionalized hydrogel}

The single-stranded DNA sequence acryl-5'-CTTCTTTCTTCCCCTTGTTTGTTG, or acryl-Hg-DNA, was purchased from Integrated DNA Technologies and incorporated into the polyacrylamide hydrogel. The DNA-functionalized polyacrylamide hydrogel was prepared based on the procedure reported by Dave et al. ${ }^{1}$ with slight modifications. Briefly, $230 \mu \mathrm{L}$ fresh gel stock solution (40 wt $\%$ acrylamide/bis-acrylamide monomers, acrylamide to bis-acrylamide molar ratio of 29:1), $115 \mu \mathrm{L} \mathrm{NaNO}_{3}\left(170 \mathrm{~g} \mathrm{~L}^{-1}\right), 230 \mu \mathrm{L}$ Tris nitrate $(92 \mathrm{mg} \mathrm{L}-1, \mathrm{pH}=7), 50 \mu \mathrm{L}$ acryl-Hg-DNA $(500 \mu \mathrm{M})$ and $1525 \mu \mathrm{L}$ Milli-Q water $(18.2 \mathrm{M} \Omega \bullet \mathrm{cm})$ were well mixed in a tube, followed by the addition of $150 \mu \mathrm{L}$ freshly prepared initiator solution $(0.1 \mathrm{~g}$ $\mathrm{mL}^{-1}$ ammonium persulfate plus 5\%(V/V) N,N,N',N'-tetramethylethylenediamine) under quick mixing.

The final gel solution was immediately pipetted into the space between two vertical, parallel glass plates separated by $0.4 \mathrm{~mm}$ plastic spacers and then polymerized at about $25{ }^{\circ} \mathrm{C}$ for $5 \mathrm{~h}^{2}$ Thereafter, using a plastic cutting ring, the newly-prepared hydrogel sheet was cut into disks with a diameter of $25 \mathrm{~mm}$. After retrieval, the hydrogel disks were washed twice in $\mathrm{pH} 7$ buffer solution $\left(1.5 \mathrm{~g} \mathrm{~L}^{-1}\right.$ Tris nitrate), each time for $8 \mathrm{~h}$, to remove residues from the hydrogel, and then stored in the same $\mathrm{pH}$ buffer for further use.

The final concentration of acryl-Hg-DNA in the hydrogel disks was $\sim 5 \mu \mathrm{M}$, and the content of $\mathrm{Hg}(\mathrm{II})$ in the prepared DNA-functionalized hydrogel disks was negligible $\left(<0.1 \mathrm{ng}\right.$ disk $\left.^{-1}\right)$, as determined by the $\mathrm{HCl}$ leaching method and the anodic 
stripping voltammetry described below. The DNA-functionalized hydrogel disks were soaked in Milli-Q water for 30 min prior to assembling into the diffusive gradients in thin films (DGT) unit. Hydrogels without DNA were also prepared by replacing DNA with Milli-Q water in the gel solution.

All the reagents used in the preparation of the DNA-functionalized hydrogel disks were of analytical grade or higher. They were obtained from Sigma-Aldrich, VWR, Mandel Scientific or Invitrogen, unless otherwise stated. The solutions and suspensions used were prepared at room temperature using Milli-Q water.

\section{SI-II: Preparation of diffusive gel}

Preparation of the agarose gels for the DNA-DGT sensor followed the procedure described by Pelcová et al. ${ }^{3}$ Briefly, 0.3 g agarose solid was dissolved in $20 \mathrm{~mL}$ Milli-Q water in an $80^{\circ} \mathrm{C}$ water bath (ISOTEMP 220, Fisher Scientific) and gently stirred to produce a homogeneous, transparent gel solution of $1.5 \mathrm{wt} \%$ agarose. The hot gel solution was immediately pipetted into the space between two preheated, vertical glass plates separated by $0.8 \mathrm{~mm}$ plastic spacers and left to cool down to room temperature. Then the newly-prepared gel sheet was cut with a plastic cutting ring into disks with a diameter of $25 \mathrm{~mm}$. Once retrieved, the agarose disks were washed three times with Milli-Q water to remove the unreacted residues and stored in Milli-Q water before use. ${ }^{4}$ Using the same measuring method as for the binding layer, the $\mathrm{Hg}(\mathrm{II})$ content in the diffusive gel disks was found to be negligible $\left(<0.1 \mathrm{ng} \operatorname{disk}^{-1}\right)$. 


\section{SI-III: Additional information on experimental setup}

The DNA-DGT sensor was assembled as follows. The DNA-functionalized hydrogel disk was placed on the cylindrical moulding base of a piston-type DGT unit (purchased from DGT Research Ltd., UK) and then covered by the agarose diffusive gel disk. In order to protect the outer surface, a $0.1 \mathrm{~mm}$ thick hydrophilic nylon membrane filter with a pore size of $0.45 \mu \mathrm{m}$ (Pall Corporation, USA) was placed on the top of the diffusive gel. Any air bubbles between each layer were carefully pushed out while keeping the layers wet and avoiding cracks in the gels. Finally, the DGT cap was placed and slowly pressed down until a tight seal between the membrane surface and the cap was achieved.

For the performance assessment of the DNA-DGT sensor, all inorganic ligand solutions were prepared using their sodium salts. For these competitive ligand series, the solution $\mathrm{pH}$ was maintained at 7 using $1.5 \mathrm{~g} \mathrm{~L}^{-1}$ Tris nitrate, except for the $\mathrm{HCO}_{3}^{-}$ series which had a $\mathrm{pH}$ value of 8 .

For each experiment, a $1 \mathrm{mg} \mathrm{L}^{-1} \mathrm{Hg}$ (II) standard solution was freshly prepared by diluting a standard stock solution $\left(1000 \mathrm{mg} \mathrm{Hg} \mathrm{L}-1, \mathrm{Hg}\left(\mathrm{ClO}_{4}\right)_{2}\right.$ in $\mathrm{H}_{2} \mathrm{O}$, Delta Scientific, Canada) with Milli-Q water. Because $\mathrm{Hg}(\mathrm{II})$ may absorb onto the walls of containers during storage, ${ }^{5}$ the $1 \mathrm{mg} \mathrm{L}^{-1} \mathrm{Hg}(\mathrm{II})$ standard solutions were routinely analyzed by the anodic stripping voltammetry method (see below). During all the experiments, the $5 \mathrm{~L}$ test solutions or water samples were stirred at $500 \mathrm{rpm}$ using magnetic stirrers. Controls consisted of DNA-DGT sensor units that were deployed in $1.5 \mathrm{~g} \mathrm{~L}^{-1}$ Tris nitrate, $\mathrm{Hg}(\mathrm{II})$-free solutions. 
A $100 \mu \mathrm{g} \mathrm{L}^{-1} \mathrm{Hg}(\mathrm{II})$ spiking concentration was selected based on experimental considerations. To maintain a stable concentration gradient across the diffusive layer and, hence, be able to use the basic DGT equation (Eq. 1 in the main text) to back calculate the $\mathrm{Hg}(\mathrm{II})$ concentration in the solution, the loss of $\mathrm{Hg}(\mathrm{II})$ mass from the test solution by uptake by the binding layer of the DNA-DGT sensor should be negligible. This can be achieved by balancing the test solution volume, deployment time and $\mathrm{Hg}(\mathrm{II})$ concentration in the laboratory. Given the 5-L volume used here, a $100 \mu \mathrm{g} \mathrm{L}^{-1}$ $\mathrm{Hg}$ (II) concentration and deployment times of up to $14 \mathrm{~h}$ fulfill the conditions for using Eq. (1) in the main text. For example, with a $8 \mathrm{~h}$ deployment of the DNA-DGT sensor, the maximum mass of $\mathrm{Hg}(\mathrm{II})$ accumulated in the binding layer was $1250 \mathrm{ng}$. This amount remains within the linear calibration range of the fluorescence method (Fig. $2 \mathrm{C}$ in the main text) and, at the same time, represents less than $0.25 \%$ of the total $\mathrm{Hg}(\mathrm{II})$ in the initial test solutions. This percentage of $\mathrm{Hg}(\mathrm{II})$ loss is entirely acceptable and will not cause significant errors in the calculation results. A deployment time much lower than $8 \mathrm{~h}$ means a higher ratio of the DGT response time to total deployment time and thus reduces the accuracy of the calculation results. A longer deployment time runs the risk of exceeding the detection range of the fluorescence method.

As can be seen in Figs. 3 and 4 of the main text, with a $\mathrm{Hg}(\mathrm{II})$ spiking concentration of $100 \mu \mathrm{g} \mathrm{L} \mathrm{L}^{-1}$, the $\mathrm{Hg}(\mathrm{II})$ mass after $8 \mathrm{~h}$ of deployment ranged from about 100 to $1250 \mathrm{ng}$ under the different scenarios tested. This mass range provides a good coverage of the calibration range of the fluorescence method, neither crowding 
at the low end nor exceeding the linear range (Fig. $2 \mathrm{C}$ in the main text). So the choice of $\mathrm{Hg}(\mathrm{II})$ spiking concentration of $\sim 100 \mu \mathrm{g} \mathrm{L^{-1 }}$ gives us confidence that both the calibration curve and the test results under variable conditions are reliable.

To eliminate unexpected $\mathrm{Hg}(\mathrm{II})$ loss via adsorption onto container walls during the experiments, the employed glass conical flasks were saturated in advance using $100 \mu \mathrm{g} \mathrm{L} \mathrm{L}^{-1} \mathrm{Hg}(\mathrm{II})$ solutions. ${ }^{3}$ Small volumes of $1000 \mathrm{mg} \mathrm{L}^{-1} \mathrm{Hg}(\mathrm{II})$ stock solution were added to compensate any observed decreases in the $\mathrm{Hg}$ (II) concentrations if necessary. After a steady $\mathrm{Hg}(\mathrm{II})$ concentration of approximately $100 \mu \mathrm{g} \mathrm{\textrm {L } ^ { - 1 }}$ was achieved, the test solutions were then used in the subsequent experiments.

In the assessment of the effects of temperature on the performance of the DNA-DGT sensor, the temperature of test solutions and water samples was adjusted by placing the solutions and samples in a temperature-controlled incubator (INTELLUS control system, PERCIVAL Scientific) for the range 5 to $25^{\circ} \mathrm{C}$ and in a water bath (ISOTEMP 220, Fisher Scientific) for the range 30 to $40^{\circ} \mathrm{C}$, both of which had a temperature accuracy of $\pm 0.1{ }^{\circ} \mathrm{C}$. The measurement of $\mathrm{pH}$ value under variable temperatures was automatically compensated by the meter's software (ORION VERSASTAR equipped with ORION 9107BNMD pH electrode, Thermo Scientific).

\section{SI-IV: Mercury(II) determination}

Once retrieved from the test solutions or water samples, the DNA-DGT sensor device was rinsed with Milli-Q water, and then carefully disassembled for $\mathrm{Hg}(\mathrm{II})$ determination. The binding hydrogel layer was carefully recovered from the DGT 
base and then stained by transferring it into a $678 \mu \mathrm{g} \mathrm{L} \mathrm{L}^{-1} \mathrm{SYBR}$ Green I solution at $25{ }^{\circ} \mathrm{C}$ for $1 \mathrm{~h} .{ }^{1}$ To quantify the fluorescence, the hydrogel was then imaged with a gel documentation system (Alpha Innotech FluorChem FC2). The hydrogel was retrieved from the staining solution and rinsed with Milli-Q water to remove unbound SYBR Green I molecules. Using plastic tweezers, the stained hydrogel was transferred with caution to the imaging glass in the cabinet. The camera was appropriately adjusted to produce optimal focus settings. The excitation wavelength for inducing the green fluorescence was set at $365 \mathrm{~nm}$, and the emission light was collected using a cooled CCD camera with the SYBR Green filter. ${ }^{1}$

Using SYBR Green $I$ as the staining dye produces a high background fluorescence, in particular at high DNA concentrations. This is reflected by the large intercept value observed in the calibration curve shown in Fig. $2 \mathrm{C}$ of the main text. The main reason for the high background is the electrostatic interaction between the DNA and SYBR Green I that produces yellow fluorescence. ${ }^{1,6}$ A possible solution to this problem is to introduce a fraction of cationic monomers (e.g., allylamine) in the polyacrylamide hydrogel preparation to promote DNA-hydrogel interaction and depress the DNA-SYBR Green I interaction. ${ }^{6}$ The cationic treatment of the binding hydrogel will be considered in the continued development and improvement of our DNA-DGT sensor units.

Wherever appropriate, the $\mathrm{Hg}(\mathrm{II})$ accumulated in the binding layer of the DGT unit was leached with $1 \%(\mathrm{~V} / \mathrm{V})$ ultra-pure $\mathrm{HCl}$ (VWR International, Canada). ${ }^{1}$ The binding layer was soaked in $5 \mathrm{~mL} 1 \% \mathrm{HCl}$ and shaken at $100 \mathrm{rpm}$ for $20 \mathrm{~min}$. After 
the $\mathrm{HCl}$ solution was collected, the hydrogel was washed with $10 \mathrm{~mL}$ Milli-Q water and then soaked in $5 \mathrm{~mL} \mathrm{pH} 7$ buffer solution (1.5 $\mathrm{g} \mathrm{L}^{-1}$ Tris nitrate) for $20 \mathrm{~min}$. This soaking-washing process was repeated at least three times until no fluorescence was observed by imaging. The leachates from the binding layer were collected, their total volume re-determined and the $\mathrm{Hg}$ (II) concentration measured with the anodic stripping voltammetry (ASV) method. The $\mathrm{Hg}(\mathrm{II})$ concentration was then used to calculate the mass of $\mathrm{Hg}$ (II) accumulated in the binding layer. At the start and end of each experiment, the $\mathrm{Hg}$ (II) concentration of the test solution or water sample was measured and the difference in concentration was compared with the mass of $\mathrm{Hg}$ (II) in the binding layer. The amount of $\mathrm{Hg}(\mathrm{II})$ accumulated in the binding layer was equal to $98 \pm 3 \%$ of that lost from the test solutions and water samples.

The ASV measurements were conducted using a 797 VA Computrace equipped with a scTRACE Gold sensor that integrates all three required electrodes (Metrohm, Application Bulletin 422/1 e). This method has a detection limit of $0.01 \mu \mathrm{g} \mathrm{L}^{-1} \mathrm{Hg}(\mathrm{II})$ with a deposition time of 120 seconds, and the calibration curve is linear up to $15 \mu \mathrm{g}$ $\mathrm{L}^{-1} \mathrm{Hg}(\mathrm{II})$. The agents used in the $\mathrm{Hg}$ (II) voltammetric determinations were of ultra-trace analysis grade, and reagent blanks were measured on a regular basis.

\section{SI-V: Hydrochemical compositions of water samples}

The natural surface water samples were collected from East Lake $\left(43.94^{\circ} \mathrm{N}, 77.16^{\circ}\right.$ W) and Fanshawe Reservoir $\left(43.05^{\circ} \mathrm{N}, 81.18^{\circ} \mathrm{W}\right)$ in Ontario, Canada. To preserve the natural water conditions, the samples were immediately transported to the 
laboratory for hydrochemical analysis and the deployment of DNA-DGT sensors.

The aqueous compositions of the artificial surface water (ASW) analogs and the natural water samples are provided in Table S1 and Table S2, respectively.

Table S1. Major ion chemistry of the Laurentian Great Lakes used in the preparation of the lake analog solutions ASW-I and ASW-II.

\begin{tabular}{cccccc}
\hline Lake & $\mathrm{pH}$ & $\begin{array}{c}\mathrm{Na}^{+a} \\
\left(\mathrm{mg} \mathrm{L}^{-1}\right)\end{array}$ & $\begin{array}{c}\mathrm{K}^{+} \\
\left(\mathrm{mg} \mathrm{L}^{-1}\right)\end{array}$ & $\begin{array}{c}\mathrm{Ca}^{2+} \\
\left(\mathrm{mg} \mathrm{L}^{-1}\right)\end{array}$ & $\begin{array}{c}\mathrm{Mg}^{2+} \\
\left(\mathrm{mg} \mathrm{L}^{-1}\right)\end{array}$ \\
\hline Superior & 6.3 & 1.38 & 0.51 & 13.62 & 2.83 \\
Michigan & 7.5 & 6.02 & 1.41 & 35.95 & 11.28 \\
Huron & 8.3 & 3.57 & 0.94 & 26.40 & 7.46 \\
East Erie & 8.2 & 7.16 & 1.43 & 32.11 & 8.89 \\
Ontario & 6.9 & 11.41 & 1.50 & 33.55 & 8.61 \\
\hline Lake & $\mathrm{Cl}^{-}$ & $\mathrm{SO}_{4}^{2-}$ & Alkalinity & $\mathrm{NO}_{3}^{-}$ & Total P \\
& $\left(\mathrm{mg} \mathrm{L}^{-1}\right)$ & $\left(\mathrm{mg} \mathrm{L}^{-1}\right)$ & $\left(\mathrm{mg} \mathrm{CaCO}_{3} \mathrm{~L}^{-1}\right)$ & $\left(\mathrm{mg} \mathrm{L}^{-1}\right)$ & $\left(\mathrm{mg} \mathrm{P} \mathrm{L}^{-1}\right)$ \\
\hline Superior & 1.42 & 3.85 & 41.9 & 1.73 & 0.003 \\
Michigan & 12.05 & 24.01 & 107.9 & 1.46 & 0.003 \\
Huron & 6.58 & 15.83 & 78.5 & 1.64 & 0.004 \\
East Erie & 14.58 & 22.81 & 88.9 & 1.15 & 0.009 \\
Ontario & 19.56 & 25.54 & 90.1 & 2.04 & 0.004 \\
\hline
\end{tabular}

Notes: ${ }^{a} \mathrm{Na}^{+}$concentration was adjusted to achieve charge balance in the PHREEQC-3 calculations.

Table S2. Hydrochemical compositions of natural surface water collected from East Lake and Fanshawe Reservoir in Ontario, Canada.

\begin{tabular}{lccccccc}
\hline & $\mathrm{pH}$ & $\begin{array}{c}\mathrm{Na}^{+a} \\
\left(\mathrm{mg} \mathrm{L}^{-1}\right)\end{array}$ & $\begin{array}{c}\mathrm{K}^{+} \\
\left(\mathrm{mg} \mathrm{L}^{-1}\right)\end{array}$ & $\begin{array}{c}\mathrm{Ca}^{2+} \\
\left(\mathrm{mg} \mathrm{L}^{-1}\right)\end{array}$ & $\begin{array}{c}\mathrm{Mg}^{2+} \\
\left(\mathrm{mg} \mathrm{L}^{-1}\right)\end{array}$ & $\begin{array}{c}\text { Total Fe } \\
\left(\mu \mathrm{g} \mathrm{L}^{-1}\right)\end{array}$ & $\begin{array}{c}\text { Total Al } \\
\left(\mu \mathrm{g} \mathrm{L}^{-1}\right)\end{array}$ \\
\hline $\begin{array}{l}\text { East Lake } \\
\text { Fanshawe } \\
\text { Reservoir }\end{array}$ & 8.11 & 8.48 & 1.35 & 41.06 & 4.59 & 7.2 & 6.1 \\
\hline & $\begin{array}{c}\mathrm{Cl}^{-} \\
\left(\mathrm{mg} \mathrm{L}^{-1}\right)\end{array}$ & $\begin{array}{c}\mathrm{F}^{-} \\
\left(\mathrm{mg} \mathrm{L}^{-1}\right)\end{array}$ & $\begin{array}{c}\mathrm{SO}_{4}^{2-} \\
\left(\mathrm{mg} \mathrm{L}^{-1}\right)\end{array}$ & $\begin{array}{c}\text { Alkalinity } \\
\left(\mathrm{mg} \mathrm{CaCO}_{3} \mathrm{~L}^{-1}\right)\end{array}$ & $\begin{array}{c}\mathrm{NO}_{3}^{-} \\
\left(\mathrm{mg} \mathrm{L}^{-1}\right)\end{array}$ & $\begin{array}{c}\text { Total P } \\
\left(\mu \mathrm{g} \mathrm{P} \mathrm{L}^{-1}\right)\end{array}$ & $\begin{array}{c}\mathrm{NPOC}^{b} \\
\left(\mathrm{mg} \mathrm{L}^{-1}\right)\end{array}$ \\
$\begin{array}{l}\text { East Lake } \\
\text { Fanshawe } \\
\text { Reservoir }\end{array}$ & 59.12 & 0.06 & 6.13 & 232.48 & 0.27 & 7.6 & 6.36 \\
\hline
\end{tabular}

Notes: ${ }^{a} \mathrm{Na}^{+}$concentration was adjusted to achieve charge balance in the PHREEQC-3 calculations; ${ }^{b}$ Total non-purgeable dissolved organic carbon. 


\section{SI-VI: Mercury(II) speciation modeling}

In the DGT principles, the delivery of target component(s) to the binding layer is considered to be majorly controlled by Fickian diffusion. ${ }^{7}$ This constitutes the theoretical base for the formulation of mass transport in models simulating the inner-work of the DGT technique. ${ }^{8}$ Thus, transport of the different $\mathrm{Hg}$ (II) species through the diffusive gel was taken into account when we modeled the speciation of $\mathrm{Hg}(\mathrm{II})$ in the binding layer of the DNA-DGT sensor.

Once transported to the binding layer, $\mathrm{Hg}$ (II) can bind to the DNA in the hydrogel. Nevertheless, the inorganic and organic ligands delivered from the test solutions or water samples to the binding layer may, in principle, continue to compete with the DNA in $\mathrm{Hg}^{2+}$ binding. The complexation constants for the reactions between $\mathrm{Hg}^{2+}$ and inorganic ligands used in the equilibrium speciation calculations with both CHEAQS Next ${ }^{9}$ and PHREEQC- $3^{10}$ are given in Table S3.

Table S3. Equilibrium constants $\left(K_{\mathrm{c}}\right)$ of the complexation reactions between $\mathrm{Hg}^{2+}$ and various inorganic and organic ligands in water at $25^{\circ} \mathrm{C}$.

\begin{tabular}{lcc}
\hline \multicolumn{1}{c}{ Complexation reaction } & $\log \boldsymbol{K}_{\mathbf{c}}$ & Reference \\
\hline $\mathbf{O H}^{-}$ & & \\
\hline $\mathrm{Hg}^{2+}+\mathrm{OH}^{-}=\mathrm{HgOH}^{+}$ & 10.42 & 11 \\
$\mathrm{Hg}^{2+}+2 \mathrm{OH}^{-}=\mathrm{Hg}(\mathrm{OH})_{2}$ & 21.83 & 11 \\
$\mathrm{Hg}^{2+}+3 \mathrm{OH}^{-}=\mathrm{Hg}(\mathrm{OH})_{3}{ }^{-}$ & 20.90 & 11 \\
$2 \mathrm{Hg}^{2+}+\mathrm{OH}^{-}=\mathrm{Hg}_{2} \mathrm{OH}{ }^{3+}$ & 10.70 & 12 \\
$3 \mathrm{Hg}^{2+}+3 \mathrm{OH}^{-}=\mathrm{Hg}_{3}(\mathrm{OH})_{3}{ }^{3+}$ & 35.60 & 12 \\
\hline $\mathbf{C l}^{-}$ & & 12 \\
\hline $\mathrm{Hg}^{2+}+\mathrm{Cl}^{-}=\mathrm{HgCl}^{+}$ & 7.30 & 12 \\
$\mathrm{Hg}^{2+}+2 \mathrm{Cl}^{-}=\mathrm{HgCl}_{2}$ & 14.00 &
\end{tabular}




\begin{tabular}{|c|c|c|}
\hline $\mathrm{Hg}^{2+}+3 \mathrm{Cl}^{-}=\mathrm{HgCl}_{3}^{-}$ & 15.00 & 12 \\
\hline $\mathrm{Hg}^{2+}+4 \mathrm{Cl}^{-}=\mathrm{HgCl}_{4}^{2-}$ & 15.60 & 12 \\
\hline $\mathrm{Hg}^{2+}+\mathrm{Cl}^{-}+\mathrm{OH}^{-}=\mathrm{HgClOH}$ & 18.25 & 12 \\
\hline \multicolumn{3}{|l|}{$\mathbf{F}^{-}$} \\
\hline $\mathrm{Hg}^{2+}+\mathrm{F}^{-}=\mathrm{HgF}^{+}$ & 1.60 & 12 \\
\hline \multicolumn{3}{|l|}{$\mathrm{SO}_{4}{ }^{2-}$} \\
\hline $\mathrm{Hg}^{2+}+\mathrm{SO}_{4}^{2-}=\mathrm{HgSO}_{4}$ & 2.41 & 12 \\
\hline $\mathrm{Hg}^{2+}+2 \mathrm{SO}_{4}{ }^{2-}=\mathrm{Hg}\left(\mathrm{SO}_{4}\right)_{2}{ }^{2-}$ & 3.47 & 12 \\
\hline \multicolumn{3}{|l|}{$\mathrm{SO}_{3}{ }^{2-}$} \\
\hline $\mathrm{Hg}^{2+}+\mathrm{SO}_{3}^{2-}=\mathrm{HgSO}_{3}$ & 10.30 & 13 \\
\hline $\mathrm{Hg}^{2+}+2 \mathrm{SO}_{3}^{2-}=\mathrm{Hg}\left(\mathrm{SO}_{3}\right)_{2}{ }^{2-}$ & 23.40 & 12 \\
\hline $\left.\mathrm{Hg}^{2+}+3 \mathrm{SO}_{3}{ }^{2-}=\mathrm{Hg}\left(\mathrm{SO}_{3}\right)_{3}\right)^{4-}$ & 24.10 & 12 \\
\hline \multicolumn{3}{|l|}{$\mathbf{S}^{2-}$} \\
\hline $\mathrm{Hg}^{2+}+\mathrm{S}^{2-}=\mathrm{HgS}$ & 7.90 & 12 \\
\hline $\mathrm{Hg}^{2+}+2 \mathrm{~S}^{2-}=\mathrm{HgS}_{2}^{2-}$ & 51.02 & 12 \\
\hline $\mathrm{Hg}^{2+}+\mathrm{S}^{2-}+\mathrm{OH}^{-}=\mathrm{HgSOH}^{-}$ & 18.50 & 12 \\
\hline $\mathrm{Hg}^{2+}+\mathrm{S}^{2-}+\mathrm{H}^{+}=\mathrm{HgHS}^{+}$ & 43.12 & 13 \\
\hline $\mathrm{Hg}^{2+}+2 \mathrm{~S}^{2-}+\mathrm{H}^{+}=\mathrm{HgHS}_{2}^{-}$ & 59.73 & 12 \\
\hline $\mathrm{Hg}^{2+}+2 \mathrm{~S}^{2-}+2 \mathrm{H}^{+}=\mathrm{HgH}_{2} \mathrm{~S}_{2}$ & 66.12 & 12 \\
\hline \multicolumn{3}{|l|}{$\mathrm{NO}_{3}^{-}$} \\
\hline $\mathrm{Hg}^{2+}+\mathrm{NO}_{3}^{-}=\mathrm{HgNO}_{3}^{+}$ & -0.43 & 12 \\
\hline $\mathrm{Hg}^{2+}+2 \mathrm{NO}_{3}^{-}=\mathrm{Hg}\left(\mathrm{NO}_{3}\right)_{2}$ & -0.81 & 12 \\
\hline \multicolumn{3}{|l|}{$\mathrm{NO}_{2}^{-}$} \\
\hline $\mathrm{Hg}^{2+}+\mathrm{NO}_{2}^{-}=\mathrm{HgNO}_{2}^{+}$ & 6.35 & 12 \\
\hline $\mathrm{Hg}^{2+}+2 \mathrm{NO}_{2}^{-}=\mathrm{Hg}\left(\mathrm{NO}_{2}\right)_{2}$ & 10.52 & 12 \\
\hline $\mathrm{Hg}^{2+}+3 \mathrm{NO}_{2}^{-}=\mathrm{Hg}\left(\mathrm{NO}_{2}\right)_{3^{-}}^{-}$ & 12.06 & 12 \\
\hline $\mathrm{Hg}^{2+}+4 \mathrm{NO}_{2}{ }^{-}=\mathrm{Hg}\left(\mathrm{NO}_{2}\right)_{4}{ }^{2-}$ & 12.27 & 12 \\
\hline \multicolumn{3}{|l|}{$\mathrm{NH}_{3}$} \\
\hline $\mathrm{Hg}^{2+}+\mathrm{NH}_{3}=\mathrm{HgNH}_{3}{ }^{2+}$ & 8.75 & 12 \\
\hline $\mathrm{Hg}^{2+}+2 \mathrm{NH}_{3}=\mathrm{Hg}\left(\mathrm{NH}_{3}\right)_{2}{ }^{2+}$ & 17.80 & 12 \\
\hline $\mathrm{Hg}^{2+}+3 \mathrm{NH}_{3}=\mathrm{Hg}\left(\mathrm{NH}_{3}\right)_{3}{ }^{2+}$ & 18.20 & 12 \\
\hline $\mathrm{Hg}^{2+}+4 \mathrm{NH}_{3}=\mathrm{Hg}\left(\mathrm{NH}_{3}\right)_{4}{ }^{2+}$ & 19.30 & 12 \\
\hline \multicolumn{3}{|l|}{$\mathrm{CO}_{3}{ }^{2-}$} \\
\hline $\mathrm{Hg}^{2+}+\mathrm{CO}_{3}^{2-}=\mathrm{HgCO}_{3}$ & 12.07 & 12 \\
\hline $\mathrm{Hg}^{2+}+2 \mathrm{CO}_{3}^{2-}=\mathrm{Hg}\left(\mathrm{CO}_{3}\right)_{2}{ }^{2-}$ & 15.57 & 12 \\
\hline $\mathrm{Hg}^{2+}+\mathrm{CO}_{3}^{2-}+\mathrm{H}^{+}=\mathrm{HgHCO}_{3}^{+}$ & 16.34 & 12 \\
\hline $\mathrm{Hg}^{2+}+\mathrm{CO}_{3}^{2-}+\mathrm{OH}^{-}=\mathrm{HgOHCO}_{3}^{-}$ & 19.20 & 12 \\
\hline \multicolumn{3}{|l|}{$\mathrm{PO}_{4}^{3-}$} \\
\hline $\mathrm{Hg}^{2+}+\mathrm{PO}_{4}^{3-}=\mathrm{HgPO}_{4}^{--}$ & 12.38 & 12 \\
\hline $\mathrm{Hg}^{2+}+\mathrm{PO}_{4}^{3-}+\mathrm{H}^{+}=\mathrm{HgHPO}_{4}$ & 20.09 & 12 \\
\hline \multicolumn{3}{|l|}{$\mathrm{C}_{6} \mathrm{H}_{5} \mathrm{O}_{7}{ }^{3-}$ (citrate) } \\
\hline $\mathrm{Hg}^{2+}+\mathrm{C}_{6} \mathrm{H}_{5} \mathrm{O}_{7}^{3-}=\mathrm{HgC}_{6} \mathrm{H}_{5} \mathrm{O}_{7}^{-}$ & 11.18 & 12 \\
\hline
\end{tabular}


In addition, the effects of water temperature on the complexation of $\mathrm{Hg}^{2+}$ with the DNA in the binding layer and the competing ligands were considered in the assessment of the DNA-DGT sensor (Test VIII, Table 1 in the main text). ${ }^{11,14-16}$ The complexation constants for $\mathrm{Hg}^{2+}$ binding to $\mathrm{OH}^{-}, \mathrm{Cl}^{-}$and the DNA in the binding layer as well as associated thermodynamic parameters are given in Table S4.

Table S4. Equilibrium constants $\left(K_{\mathrm{c}}\right)$ at $25{ }^{\circ} \mathrm{C}$ and reaction enthalpies $\left(\Delta H_{\mathrm{m}}\right)$ of the complexation reactions of $\mathrm{Hg}^{2+}$ with the DNA sequences and inorganic ligands. The enthalpies are assumed constant in the $5-50{ }^{\circ} \mathrm{C}$ range and used in the van't Hoff equation to correct the equilibrium constants for variable temperature.

\begin{tabular}{|c|c|c|c|}
\hline Complexation reaction & $\log K_{\mathrm{c}}\left(25^{\circ} \mathrm{C}\right)$ & $\Delta H_{\mathrm{m}}\left(\mathrm{kJ} \mathrm{mol}^{-1}\right)$ & References \\
\hline \multicolumn{4}{|l|}{ Acryl-Hg-DNA } \\
\hline $2 \mathrm{RNC}_{5} \mathrm{H}_{4} \mathrm{O}_{2} \mathrm{NH}+\mathrm{Hg}^{2+}=$ & 19.80 & -81.27 & 17 \\
\hline \multicolumn{4}{|l|}{$\mathrm{Hg}\left(\mathrm{RNC}_{5} \mathrm{H}_{4} \mathrm{O}_{2} \mathrm{~N}\right)_{2}+2 \mathrm{H}^{+}$} \\
\hline \multicolumn{4}{|l|}{$\mathbf{O H}^{-}$} \\
\hline $\mathrm{Hg}^{2+}+\mathrm{OH}^{-}=\mathrm{HgOH}^{+}$ & 10.42 & -25.68 & 11 \\
\hline $\mathrm{Hg}^{2+}+2 \mathrm{OH}^{-}=\mathrm{Hg}(\mathrm{OH})_{2}$ & 21.83 & -66.32 & 11 \\
\hline $\mathrm{Hg}^{2+}+3 \mathrm{OH}^{-}=\mathrm{Hg}(\mathrm{OH})_{3}^{-}$ & 20.90 & -39.90 & 11 \\
\hline $2 \mathrm{Hg}^{2+}+\mathrm{OH}^{-}=\mathrm{Hg}_{2} \mathrm{OH}^{3+}$ & 10.70 & -30.34 & 15 \\
\hline $3 \mathrm{Hg}^{2+}+3 \mathrm{OH}^{-}=\mathrm{Hg}_{3}(\mathrm{OH})_{3}^{3+}$ & 35.60 & -80.23 & 15 \\
\hline \multicolumn{4}{|l|}{$\mathrm{Cl}^{-}$} \\
\hline $\mathrm{Hg}^{2+}+\mathrm{Cl}^{-}=\mathrm{HgCl}^{+}$ & 7.30 & -22.65 & 11 \\
\hline $\mathrm{Hg}^{2+}+2 \mathrm{Cl}^{-}=\mathrm{HgCl}_{2}$ & 14.00 & -52.87 & 11 \\
\hline $\mathrm{Hg}^{2+}+3 \mathrm{Cl}^{-}=\mathrm{HgCl}_{3}^{-}$ & 15.00 & -58.04 & 11 \\
\hline $\mathrm{Hg}^{2+}+4 \mathrm{Cl}^{-}=\mathrm{HgCl}_{4}^{2-}$ & 15.60 & -56.39 & 11 \\
\hline $\mathrm{Hg}^{2+}+\mathrm{Cl}^{-}+\mathrm{OH}^{-}=\mathrm{HgClOH}$ & 18.25 & -62.53 & 11 \\
\hline
\end{tabular}

\section{SI-VII: Additional results}

\section{VII-1: Mercury(II) uptake by the DNA-functionalized binding layer}

The use of Eq. (1) in the main text requires that the $\mathrm{Hg}(\mathrm{II})$ concentration at the 
diffusive layer/binding layer interface in the DNA-DGT sensor is effectively zero. ${ }^{7}$ And to satisfy this requirement, the uptake of $\mathrm{Hg}(\mathrm{II})$ by the DNA-functionalized hydrogel needs to be fast sufficiently.

When steady-state diffusion across the diffusive layer is achieved, Fick's first law can be used to describe the flux $(F)$ of $\mathrm{Hg}$ (II) across the diffusive layer (including the filter membrane): ${ }^{18}$

$$
F=D \frac{\partial c}{\partial x}=D \frac{c-c^{\prime}}{\Delta g+\delta}
$$

where $D$ is the diffusion coefficient of $\mathrm{Hg}$ (II) species in the diffusive layer, $c$ is the $\mathrm{Hg}$ (II) concentration in the solution, $c^{\prime}$ is $\mathrm{Hg}(\mathrm{II})$ concentration at the diffusive layer/binding layer interface, $\Delta g$ is the diffusion thickness $(0.9 \mathrm{~mm}$ for the DNA-DGT sensor), and $\delta$ is the thickness of the diffusive boundary layer.

Assuming that $c^{\prime}$ is effectively zero and $\delta$ is negligible relative to $\Delta g$, we can obtain the simplified equation below:

$$
F=D \frac{c}{\Delta g}
$$

According to Eq. (S2), the $\mathrm{Hg}(\mathrm{II})$ flux through the diffusive layer of the DNA-DGT sensor is estimated to be $0.01 \mathrm{ng} \mathrm{cm}^{-2} \mathrm{~s}^{-1}$ at $25{ }^{\circ} \mathrm{C}$ for a solution $\mathrm{Hg}$ (II) concentration of $100 \mu \mathrm{g} \mathrm{L} \mathrm{L}^{-1}$ and a diffusion coefficient of $9 \times 10^{-6} \mathrm{~cm}^{2} \mathrm{~s}^{-1}$. The flux would be even lower for a diffusion coefficient of $9.8 \times 10^{-7} \mathrm{~cm}^{2} \mathrm{~s}^{-1}$ as estimated for $\mathrm{Hg}(\mathrm{II})$ complexed with Suwannee River Fulvic Acid. A rise of the $\mathrm{Hg}$ (II) diffusion coefficient to $1.3 \times 10^{-5} \mathrm{~cm}^{2} \mathrm{~s}^{-1}$ (see section VII-4 below) at $40{ }^{\circ} \mathrm{C}$ would increase the flux slightly to $0.014 \mathrm{ng} \mathrm{cm}^{-2} \mathrm{~s}^{-1}$.

Our previous study ${ }^{1}$ for the DNA-functionalized hydrogel showed that when 
directly immersed without DGT holder in $\mathrm{Hg}$ (II) solutions, the gel with a surface area of $1.1 \mathrm{~cm}^{2}$ has a first order $\mathrm{Hg}(\mathrm{II})$ uptake rate constant of about $5 \mathrm{~h}^{-1}$. This equates to a $\mathrm{Hg}$ (II) flux of about $0.25 \mathrm{ng} \mathrm{cm}^{-2} \mathrm{~s}^{-1}$ for the DNA-functionalized hydrogel directly immersed in solution (as illustrated in Fig. 1B of the main text). Thus, $\mathrm{Hg}(\mathrm{II})$ uptake by the DNA-functionalized binding hydrogel is much faster than the diffusive transport in the DNA-DGT sensor, thereby ensuring a (near-)zero $\mathrm{Hg}$ (II) concentration at the diffusive layer/binding layer interface. ${ }^{18}$

The systematic agreement between the calculated $c_{\text {DGT }}$ values (after calibration) and the spiked $\mathrm{Hg}$ (II) concentrations further implies that the condition of fast uptake holds across all the experiments performed in our study (Figs. 3-5 in the main text). More broadly, this good agreement supports the validity of the assumptions on which the DGT basic equation is built (Eq. 1 in the main text). ${ }^{1,7}$ In turn, the modeling results imply that the conditions for the use of the DNA-DGT sensor are met.

\section{VII-2: Detection limit of the DNA-DGT sensor}

To generate a signal that is 3 times the standard deviation of the noise $(0.14$ a.u.) in the fluorescence measurements, the mass of $\mathrm{Hg}(\mathrm{II})$ accumulated in the DNA-functionalized binding hydrogel needs to be at least $5 \mathrm{ng}$. This mass is considered the lowest $\mathrm{Hg}(\mathrm{II})$ amount that the DNA-DGT sensor can respond to. When converting this mass to the method detection limit, one needs to consider the deployment time and dimensions of the DGT device. ${ }^{18}$

For example, imposing a deployment time of $8 \mathrm{~h}$ at $25^{\circ} \mathrm{C}$ and the dimensions of 
the DNA-DGT sensor used in our study, the detection limit for aqueous $\mathrm{Hg}$ (II) according to Eq. (1) in the main text is $0.55 \mu \mathrm{g} \mathrm{\textrm {L } ^ { - 1 }}$. This value is lower than the WHO recommended drinking water limit of $1 \mu \mathrm{g} \mathrm{L}{ }^{-1} \mathrm{Hg} .{ }^{19}$ Thus, the DNA-DGT sensor has the capability to screen $\mathrm{Hg}(\mathrm{II})$-contaminated natural waters.

Note that we assume a deployment time of $8 \mathrm{~h}$ in the above calculation, whereas in real-world situations a longer deployment time can be used to accumulate $\mathrm{Hg}$ (II) to $5 \mathrm{ng}$. This essentially means that a lower detection limit for $\mathrm{Hg}(\mathrm{II})$ in water can be obtained even with the same DNA-DGT sensor.

\section{VII-3: Mercury(II) speciation in inorganic ligand solutions}

The predicted equilibrium distributions of $\mathrm{Hg}$ (II) species in the solutions used for the tests of potentially competing inorganic ligands (Tests III-VI, Table 1 in the main text) were calculated with PHREEQC-3. ${ }^{10}$ The results are shown in Fig. S1. Note that in the presence of $\mathrm{Cl}^{-}$, the $\mathrm{Hg}(\mathrm{II})-\mathrm{Cl}$ inorganic complexes were the major $\mathrm{Hg}(\mathrm{II})$ species in the solutions (Fig. S1A). 
(A)

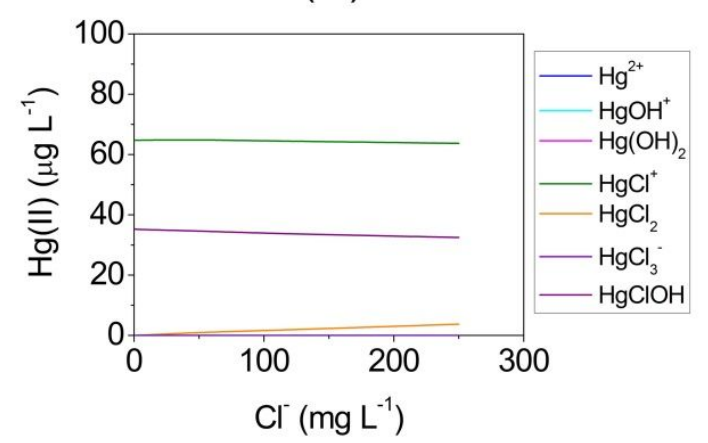

(C)

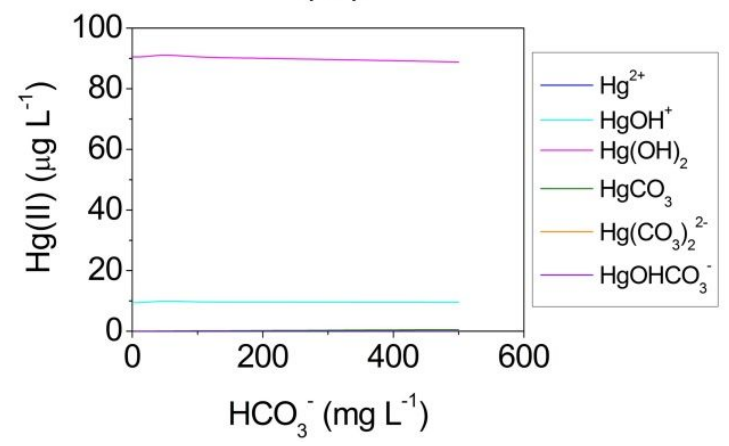

(B)

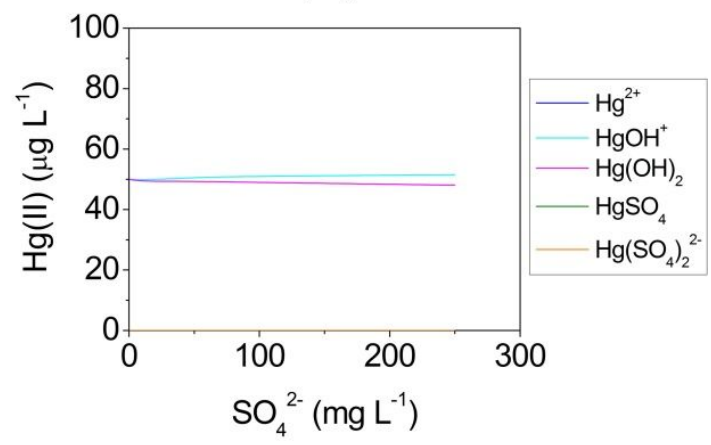

(D)

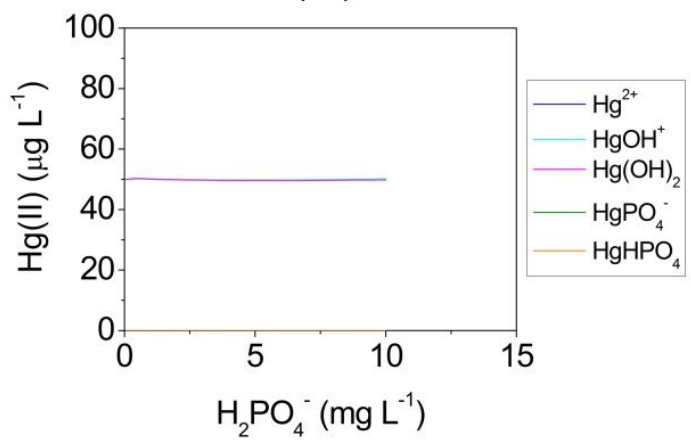

Figure S1. Distributions of aqueous $\mathrm{Hg}(\mathrm{II})$ species as a function of various inorganic ligand concentrations in the initial solutions spiked with $100 \pm 2 \mu \mathrm{g} \mathrm{L}^{-1} \mathrm{Hg}(\mathrm{II})$. These solutions were used to test potentially competing effects at $\mathrm{pH}$ 7, except for $\mathrm{HCO}_{3}{ }^{-}$ where $\mathrm{pH}$ was 8 (Tests III-VI, Table 1 in the main text).

\section{VII-4: Temperature-dependent diffusion coefficients of mercury(II) species}

The diffusion coefficients of various $\mathrm{Hg}$ (II) species must be temperature-corrected when calculating the $c_{\text {DGT }}$ values. As addressed in the main text, it can be assumed that the diffusion coefficients for the complexes of $\mathrm{Hg}^{2+}$ with different inorganic ligands $\left(\mathrm{Cl}^{-}, \mathrm{SO}_{4}^{2-}, \mathrm{HCO}_{3}^{-}, \mathrm{H}_{2} \mathrm{PO}_{4}^{-}\right)$are the same at a given temperature. Hence, a single diffusion coefficient ( $D_{\text {inorg }}$ ) is assigned to the inorganic $\mathrm{Hg}(\mathrm{II})$ species (Table S5). Similarly, a single diffusion coefficient ( $\left.D_{\text {org }}\right)$ is used to describe the diffusion through the agarose gel of the complexes between $\mathrm{Hg}^{2+}$ and natural dissolved organic matter (NDOM). 
Table S5. The diffusion coefficients of inorganic and organic complexes of $\mathrm{Hg}(\mathrm{II})$ as a function of temperature in the range $5-40{ }^{\circ} \mathrm{C}$.

\begin{tabular}{ccc}
\hline Temperature $\left({ }^{\circ} \mathrm{C}\right)$ & $D_{\text {inorg }}\left(\mathrm{cm}^{2} \mathrm{~s}^{-1}\right)$ & $D_{\text {org }}\left(\mathrm{cm}^{2} \mathrm{~s}^{-1}\right)$ \\
\hline 5 & $4.86 \times 10^{-6}$ & $5.29 \times 10^{-7}$ \\
10 & $5.76 \times 10^{-6}$ & $6.28 \times 10^{-7}$ \\
15 & $6.75 \times 10^{-6}$ & $7.35 \times 10^{-7}$ \\
20 & $7.83 \times 10^{-6}$ & $8.53 \times 10^{-7}$ \\
25 & $9.00 \times 10^{-6}$ & $9.80 \times 10^{-7}$ \\
30 & $1.03 \times 10^{-5}$ & $1.12 \times 10^{-6}$ \\
35 & $1.16 \times 10^{-5}$ & $1.26 \times 10^{-6}$ \\
40 & $1.30 \times 10^{-5}$ & $1.42 \times 10^{-6}$ \\
\hline
\end{tabular}

Notes: $D_{\text {inorg }}$ and $D_{\text {org }}$ indicate the diffusion coefficients of inorganic $\mathrm{Hg}$ (II) species $\left(\mathrm{Hg}^{2+}\right.$ complexed with $\mathrm{Cl}^{-}, \mathrm{SO}_{4}{ }^{2-}, \mathrm{HCO}_{3}{ }^{-}$and $\mathrm{H}_{2} \mathrm{PO}_{4}{ }^{-}$) and organic $\mathrm{Hg}$ (II) species (determined here using $\mathrm{Hg}^{2+}$ complexed with Suwannee River Fulvic Acid), respectively.

\section{VII-5: Mercury(II) speciation in the artificial surface water solutions}

Based on the equilibrium speciation calculations, the initial distributions of $\mathrm{Hg}$ (II) species prior to the deployment of the DNA-DGT sensor in the two types of artificial surface water (ASW, Tests IX and X, Table 1 in the main text) are shown in Fig. S2.

(A) ASW-I

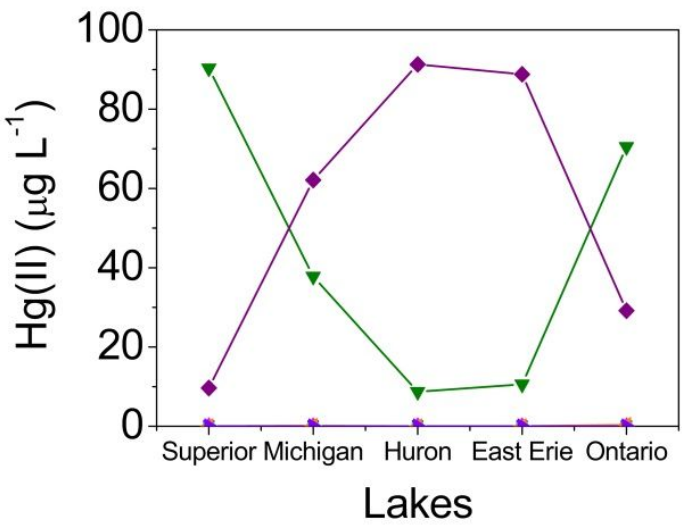

(B) ASW-II

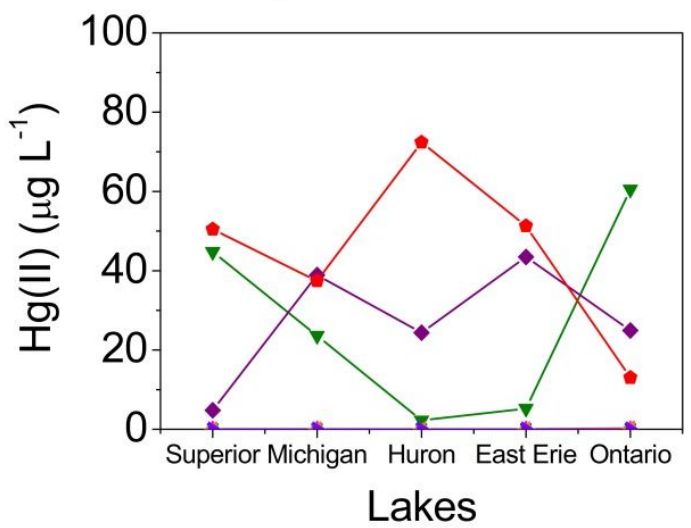

$\begin{array}{cl}\text { Modeled } & -\square-\mathrm{Hg}^{2+}-\bullet-\mathrm{HgOH}^{+}-\wedge-\mathrm{Hg}(\mathrm{OH})_{2}-\nabla-\mathrm{HgCl}^{+}-\triangleleft-\mathrm{HgCl}_{2} \\ \mathrm{Hg}(\mathrm{II}) \text { species: } & \rightarrow-\mathrm{HgCl}_{3}^{-} \rightarrow-\mathrm{HgClOH}_{-}-\mathrm{Hg}(\mathrm{II})-\mathrm{SRFA}\end{array}$

Figure S2. Distributions of aqueous $\mathrm{Hg}(\mathrm{II})$ species in the two types of artificial 
surface water (ASW) solutions spiked with $100 \pm 2 \mu \mathrm{g} \mathrm{L}^{-1} \mathrm{Hg}(\mathrm{II})$ and prior to the deployment of the DNA-DGT sensor. The hydrochemical compositions of ASW-I are given in Table S1. Relative to ASW-I, the ASW-II solutions had an added $10 \mathrm{mg}$ DOC L ${ }^{-1}$ of Suwannee River Fulvic Acid (SRFA).

\section{VII-6: Mercury(II) speciation in the natural water samples}

The predicted $\mathrm{Hg}(\mathrm{II})$ equilibrium speciation in the two natural water samples after spiking with 20,50 or $100 \mu \mathrm{g} \mathrm{L}^{-1} \mathrm{Hg}(\mathrm{II})$, and prior to the deployment of the DNA-DGT sensor, is shown in Fig. S3.

(A) East Lake water

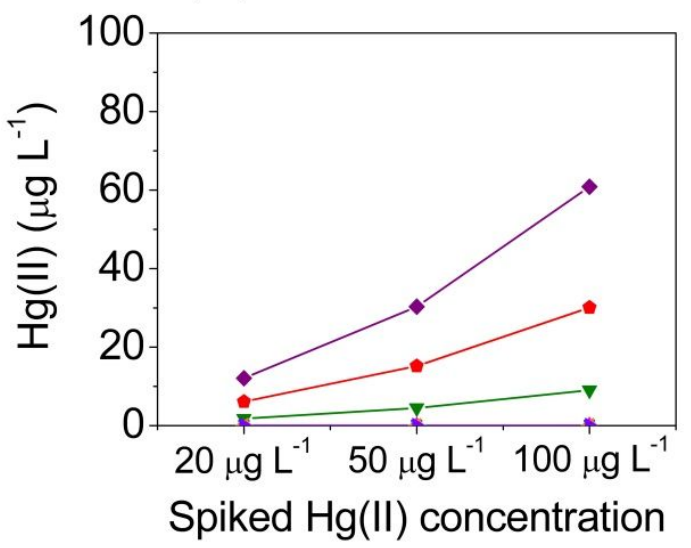

(B) Fanshawe Reservoir water

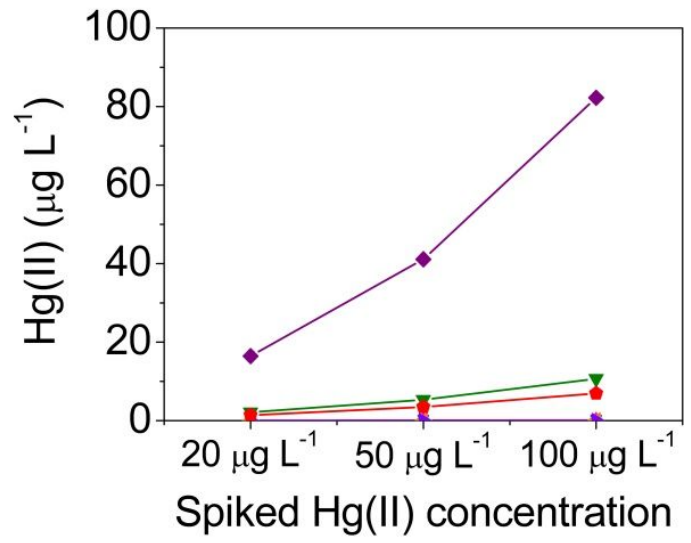

Modeled $-\square-\mathrm{Hg}^{2+}-\bullet-\mathrm{HgOH}^{+}-\triangle-\mathrm{Hg}(\mathrm{OH})_{2}-\nabla-\mathrm{HgCl}^{+}-\triangleleft-\mathrm{HgCl}_{2}$ $\mathrm{Hg}(\mathrm{II})$ species: $\rightarrow-\mathrm{HgCl}_{3}^{-} \longrightarrow-\mathrm{HgClOH} \rightarrow-\mathrm{Hg}(\mathrm{II})-\mathrm{DOM}$

Figure S3. Distributions of aqueous $\mathrm{Hg}$ (II) species in the two natural water samples that were spiked with 20,50 or $100 \mu \mathrm{g} \mathrm{L} \mathrm{L}^{-1} \mathrm{Hg}(\mathrm{II})$, prior to the deployment of the DNA-DGT sensor. The hydrochemical compositions of the natural water are provided in Table S2. 


\section{References}

(1) Dave, N.; Chan, M. Y.; Huang, P.-J. J.; Smith, B. D.; Liu, J. Regenerable DNA-functionalized hydrogels for ultrasensitive, instrument-free mercury(II) detection and removal in water. J. Am. Chem. Soc. 2010, 132, 12668-12673.

(2) Ding, S.; Xu, D.; Sun, Q.; Yin, H.; Zhang, C. Measurement of dissolved reactive phosphorus using the diffusive gradients in thin films technique with a high-capacity binding phase. Environ. Sci. Technol. 2010, 44, 8169-8174.

(3) Pelcová, P.; Dočekalová, H.; Kleckerová, A. Development of the diffusive gradient in thin films technique for the measurement of labile mercury species in waters. Anal. Chim. Acta 2014, $819,42-48$.

(4) Zhang, H.; Davison, W. Diffusional characteristics of hydrogels used in DGT and DET techniques. Anal. Chim. Acta 1999, 398, 329-340.

(5) Lo, J.; Wai, C. Mercury loss from water during storage: Mechanisms and prevention. Anal. Chem. 1975, 47, 1869-1870.

(6) Joseph, K.; Dave, N.; Liu, J. Electrostatically directed visual fluorescence response of DNA-functionalized monolithic hydrogels for highly sensitive $\mathrm{Hg}^{2+}$ detection. ACS Appl. Mater. Interfaces 2011, 3, 733-739.

(7) Davison, W.; Zhang, H. Progress in understanding the use of diffusive gradients in thin films (DGT) - back to basics. Environ. Chem. 2012, 9, 1-13.

(8) Zhang, H.; Davison, W.; Miller, S.; Tych, W. In situ high resolution measurements of fluxes of $\mathrm{Ni}, \mathrm{Cu}, \mathrm{Fe}$, and $\mathrm{Mn}$ and concentrations of $\mathrm{Zn}$ and $\mathrm{Cd}$ in porewaters by DGT. Geochim. Cosmochim. Acta 1995, 59, 4181-4192.

(9) Verweij, W. CHEAQS (a program for calculating CHemical Equilibria in AQuatic Systems). http://www.cheaqs.eu. 2018.

(10) Parkhurst, D. L.; Appelo, C. A. J. Description of input and examples for PHREEQC version 3 - A computer program for speciation, batch-reaction, one-dimensional transport, and inverse geochemical calculations. U.S. Geological Survey Techniques and Methods 2013, Book 6, Chap. A43, $497 \mathrm{p}$.

(11) Di Natale, F.; Erto, A.; Lancia, A.; Musmarra, D. Mercury adsorption on granular activated carbon in aqueous solutions containing nitrates and chlorides. J. Hazard. Mater. 2011, 192, 1842-1850.

(12) Martell, A.; Smith, R.; Motekaitis, R. NIST standard reference database 46 version 8.0. NIST critically selected stability constants of metal complexes database, US Department of Commerce, National Institute of Standards and Technology 2004.

(13) Hsu-Kim, H.; Kucharzyk, K. H.; Zhang, T.; Deshusses, M. A. Mechanisms regulating mercury bioavailability for methylating microorganisms in the aquatic environment: A critical review. Environ. Sci. Technol. 2013, 47, 2441-2456.

(14) Tipping, E.; Lofts, S.; Sonke, J. Humic Ion-Binding Model VII: a revised parameterisation of cation-binding by humic substances. Environ. Chem. 2011, 8, 225-235.

(15) Stumm, W.; Morgan, J. J. Aquatic chemistry: Chemical equilibria and rates in natural waters. 3rd ed., John Wiley \& Sons: New York, 1996; Vol. 126.

(16) Fein, J. B.; Williams-Jones, A. The role of mercury-organic interactions in the hydrothermal transport of mercury. Econ. Geol. 1997, 92, 20-28. 
(17) Pi, K.; Liu, J.; Van Cappellen, P. A DNA-based biosensor for aqueous Hg(II): Performance under variable $\mathrm{pH}$, temperature and competing ligand composition. J. Hazard. Mater. 2020, 385, 121572 .

(18) Luo, J.; Zhang, H.; Santner, J.; Davison, W. Performance characteristics of diffusive gradients in thin films equipped with a binding gel layer containing precipitated ferrihydrite for measuring arsenic(V), selenium(VI), vanadium(V), and antimony(V). Anal. Chem. 2010, 82, 8903-8909.

(19) World Health Organization. Guideline for Drinking-Water Quality, 4 ${ }^{\text {th }}$ ed. Geneva, Switzerland, 2011. 